\title{
EXTENSIVE READING IN EFL SETTINGS: A SPECIAL INTERVIEW WITH PROFESSOR PAUL NATION
}

\section{Yuseva Ariyani Iswandaria, Lanoke Intan Paradita}

\author{
('yuseva.iswandari@gmail.com) \\ Universitas Sanata Dharma \\ Mrican, Tromol Pos 29, Yogyakarta, Indonesia, 55002 \\ ('lantaranta@gmail.com) \\ Universitas Muhammadiyah Yogyakarta \\ Jl. Brawijaya, Kasihan, Bantul, Yogyakarta, Indonesia, 55183
}

DOI: http://dx.doi.org/10.15639/teflinjournal.v30i2/187-196

\begin{abstract}
We are very honored to have this great opportunity to interview Professor Paul Nation for the TEFLIN Journal's themed issue on Extensive Reading. Professor Paul Nation is an Emeritus Professor of Applied Linguistics in the School of Linguistics and Applied Language Studies at Victoria University of Wellington, New Zealand. His special interests are on language teaching methodologies and vocabulary acquisition, mainly for English as a Foreign Language. He has taught in many countries including Indonesia, Finland, Japan, Thailand, and the United States. He has published numerous books and articles, including a four-series Reading for Speed and Fluency published by Compass Publishing in 2007. He introduced the 'four strands' approach to balance learning opportunities in language courses and classes.

Using his vast experience in ELT and language teaching methodology, Professor Paul Nation shares his viewpoints on Extensive Reading in EFL settings, which has gained more attention among teachers and language practitioners whose passion are on reading. This attention has increased especially after the Indonesian Extensive Reading Association (IERA) was established in 2016 with the help of the Extensive Reading Foundation.
\end{abstract}




\section{We would like to thank you for this great opportunity for us to interview you. First of all, would you please tell us a little bit about you and your academic work?}

Thank you Yuseva and Lanoke. It is really an honor for me to share a little bit for the TEFLIN Journal's themed issue on Extensive Reading. I am an emeritus professor in Applied Linguistics and Applied Language Studies at Victoria University of Wellington, New Zealand. My special interests are on the teaching and learning of vocabulary and language teaching methodology. I have taught in many places, such as, Thailand, Japan, the United States, Finland, and of course Indonesia. So, Indonesia is very familiar to me.

I was teaching in Indonesia back in 1972 at IKIP Negeri Yogyakarta and also at Sanata Dharma University, where you are teaching now, Yuseva. I mainly taught reading, and that was when I initiated an extensive reading program for the first time at IKIP Negeri Yogyakarta. In addition to teaching, I also published some articles with my Indonesian students and colleagues. The following are the examples:

- Bismoko, J., \& Nation, I. S. P. (1972) Reading speed and transfer of training. Publikasi Ilmu Keguruan Sastra Seni, 2(2), 3-5.

- Bismoko, J., \& Nation, I. S. P. (1974) English reading speed and the mother-tongue or national language. RELC Journal, 5(1), 86-89.

- Sukardi, M. J. U., \& Nation, I. S. P. (1974). English vocabulary tests. Yogyakarta: Penerbitan Yayasan Kanisius.

\section{In your perspectives, what are some of the key factors that contribute to the success of English language teaching and learning in an EFL setting?}

In my perspective, teachers should give a balance of opportunities for learning across the four strands of meaning-focus input and meaning-focus output, language focus learning and fluency development. The four strands are: (1) meaning-focused input (learning through listening and reading), (2) learning-focused output (learning through speaking and writing), (3) languagefocused learning, and (4) fluency development. 


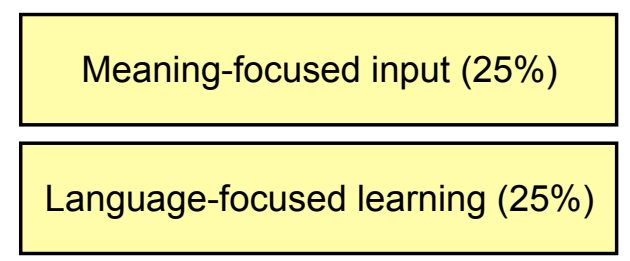

Meaning-focused output 25\%)

Fluency Development (25\%)

Figure 1. The Principle of the Four Strands (Nation, 2007)

However, there is something that I see not going well with foreign language learning and teaching. Some of the strands are often neglected or that they do not get enough time. Meanwhile, other strands are getting too far and take much of the time. In Indonesia, particularly during my teaching time, the one which seemed to be emphasized more by teachers was language-focused learning. Instead of making up about a quarter of the course $(25 \%)$, it often made up more than 70 to $80 \%$ of the course. I hope teachers nowadays have successfully balanced those four strands in their language classes.

One thing to believe is that teaching is not teachers' most important job. It is only a small part of their work. I see that planning and organizing are two most important jobs of teachers. First, it is more important for teachers to plan a course so that useful material is being used and focused on. This is to create a balance of these learning opportunities across the four strands. The number 2 job of teachers is to organize a classroom so that each strand has an equal opportunity to exist in order for the teachers to run the class activities well.

\section{How does extensive reading work in the four strands?}

ER is meaning-focused input where the students get the input which is at the right level. This means that students only get few unknown words and that becomes the way they make progress and learn. To take the most benefit from meaning-focused input, half of the input should be extensive reading and the other half is extensive listening. An extensive reading program should also include another strand, that is, fluency development because if you can read faster you can read more. This can be reached by allowing students to spend one third of their time to read really easy graded readers, those are books that have lower levels, or reading the same book repeatedly just so they could read faster. This means that a reading or extensive reading program is required to 
have two parts: the two-thirds of it is reading at the right level and the other one-third is reading at a really easy level so that you can read faster. The purpose of this distribution is to develop fluency which at the same time also allows students to read more.

\section{How do you see the potential of reading in helping the English acquisition process?}

I would say it is very essential and an extensive reading course in particular should be making up around about just under a quarter of the total learning time. Extensive reading really helps students' English acquisition process, and it's very easy to do. I suggest you go to my website https://www.victoria.ac.nz/lals/about/staff/paul-nation. Under the TUJ Reading heading, there are some articles that I put up there for a course I taught in Japan. I recommend teachers to go to a study on "Book Flood" by Francis Mangubhai and Warwick B. Elley. This study shows that with a very minimum teacher training, which is about two or three hours, teachers can run a very successful Extensive Reading program and have very impressive results from doing it. The studies on extensive reading where Elley's findings were adopted were about students spending their great amount of their lesson time reading books that were of their interest. The finding reveals how extensive reading helps to increase the students' language growth.

Furthermore, as I have mentioned before that I taught in IKIP Yogyakarta in 1972. I had a chance to set up an extensive reading program for my students. It was actually quite easy because there were a few graded readers already in the library. I started it quite simple by collecting all the graded readers together, buying some more, and having students read as much as they could. I sat in front and the students read in the classroom because I wanted to make sure that they did it. One important thing in doing ER is that the teachers only need to make sure that the class has the books, the students know what to do, and do it. The teachers mustn't interfere much after that. Once my students finished reading, they would come in front one by one and had a conversation about the books with me. They could also ask questions. Yes, I interrupted at least one student every few minutes, but on the other hand the rest of the class spent a lot of time reading.

The students found that the reading activity in extensive reading appeared to be an individual activity where they could choose books of their own 
proficiency levels. They could also have their personal book preferences based on their interests and, therefore, they became more motivated to read. One clear thing I observed was that these students had very strong English proficiency after joining the ER program. One of the ways I knew was when I went back to Indonesia again 20 years later, some people who were in my classes and joined my extensive reading program became the staff of IKIP. They mentioned that they continued building their reading habit ever since. One result of it was that their English proficiency was so good that they were accepted to be lecturers in the teaching training college.

\section{To what extent does ER help the students to become autonomous learners?}

I think it is a good goal for the teacher to have. When you start ER, you need to start in the classroom, so that the learners do it and you have to make sure that it is being done. As the learners get more interested, they get more motivated about the reading, then the reading can be done outside the classroom. However, the teacher should do a little bit of autonomy training. The learners have to know their vocabulary size and how many words they need to learn in order to be able to read newspapers and to read non-simplified books. The students also need to understand why they are doing ER and how it helps them. The teacher should train the students to see that they should be reading lots of books in order to get plenty of repetition of the words. By then, students have the chance of learning and they can move on to the books which are slightly more difficult. The students have to understand this simple step so that the teacher does not need to repeatedly instruct the students.

\section{What do we need to consider when we want to start an extensive reading program? How important are graded readers for this program?}

One of the first things I would be doing before setting up an ER program would be giving some of typical kind of learners a test on their vocabulary knowledge of the first to perhaps the third thousand words. I would use the result of their test to do an ER program with graded readers which are at their level. There are lots of tests around. On my website (https://www.victoria.ac.nz/lals/about/staff/paul-nation\#vocab-tests) there are two new tests for testing how many words learners know. First is the updated 
vocabulary levels test and another one is called the new vocab level test from Stuart McLean and Brandon Kramer. You can use either of these tests and parts of either one of these to measure how many words your learners know.

The other thing I will consider is the students' age level. Some graded readers are for young learners and some are for older learners and so on. Therefore, I think it is quite useful to try to match to the books. You can use children's books for students to read; however, they are not as good as graded readers. It is because children's books are designed for native speakers. Five to six year old native speakers have vocabulary of at least 3000-4000 words. This means that in the books written for children, there are words which are way beyond the first or second thousand word levels. For someone who is not a native speaker, therefore, these words then become quite difficult and there is quite a lot of them. Therefore, if you haven't got graded readers, children's book are okay, but they are not as good as graded readers. The main effect of graded readers is to get rid of words which are way beyond the students'

current level. That's the most important effect. However, it does not matter if you haven't got the books that are exactly right for the learners because it is doing the reading which is important. This is also to point out that a teacher's main job with ER is making the books available, that the learners are pushed to read, and then let them get on to the job. I think trying to give the teacher more to do is not the way to deal with ER. Whenever the ER time comes around, the teacher should say "Good, now I can have a rest".

\section{So, would you say that graded readers are particularly crucial for EFL settings?}

Yes, that is why graded readers are there. Graded readers are not for ESL learners. In a second language setting where people learning English such as in New Zealand, graded readers are not needed. Young children in ESL settings start learning like native speakers. Young learners who are immigrants quickly just behave like native speakers after a few months of being in a true ESL setting. Their vocabulary size increases about a thousand words a year because they have so much opportunity to learn. They would be reading normal books though you could use graded readers with adults to a very low proficiency in ESL setting.

In an EFL setting, however, graded readers are really important. If your vocabulary level is less than 3000 words you should be reading graded readers 
because there is no way you can get material at the right level which is not heavily loaded with unknown words unless you read graded readers. If you do not have graded readers you cannot have ER at the beginning and intermediate proficiency levels. It is as simple as that. If you use other books, it will no longer be ER because the books are not at the right level for the learners and they are just too difficult. In case of the minimum availability of graded readers, the easiest way to set up an ER program is to use online ER program, such as XReading.com. Although it is not free, I think it is still affordable (please visit https://xreading.com/ for more information). Students will get the books, the tests and the record keeping in the program. This means that students do not have to buy the books.

\section{What can we do to address problems that often occur such as teachers' unfamiliarity with extensive reading and students' lack of motivation in reading?}

The easiest way to get people interested in ER is to get them to do some ER. In this way, too, this connects with the teacher. There is a study in Korea about one teacher trying to convince other teachers about extensive reading and how good it is (see Byun, 2010). One of the things this teacher did was to get the other teachers to read two or three graded readers because they had never seen graded readers before and never read them. When the teachers did, they found that the stories were good, interesting and easy. As a result, they eventually could see what the point of ER was. ER was reading without struggling on every page and on every line. ER is not reading difficult materials that bring new words in which students have to look up at the dictionary (intensive reading). The point is that you have to also be readers because if you have not done reading yourself, you are not in a good position to tell other people to do it or to force other people to do it.

That is the same with learners. I think you have to force learners to do ER by getting them to do ER in class. If they are very reluctant, you have to make the completion of the ER part of the grade of their course. You can use such tests that are available in Mreader (www.mreader.org) or Paul Goldberg's XReading website as a way of grading their reading progress. It is among many options that teachers can choose to do the grading and also record students' reading. I think it is important to get people to do extensive reading, and you 
will find that many of the problems then disappear once they realized what it is, how easy it is, and how enjoyable it can be.

\section{In terms of assessment, how should we assess students' progress in ER?}

The number one is quantity of reading. The student who does the most reading should be getting the higher grades in ER. Another assessment you can do is comprehension test. However, it is important to note that we do not say higher comprehension is better than lower comprehension. What we tell to our students is that they must score a certain level of comprehension or we do not count the book they are reading as the book the students have read. The students, then, have to go back and either read it again or read different book to get it counted.

When I was running the ER program in Yogyakarta, I crafted a reading record using one sheet of paper that the students would always bring. This was important because the students should be reading more than one book a week. For the record, I divided the paper into 16 squares. In each square, the student wrote the date, the name of the book, the level of the book, and if he or she liked it. It was very simple. As they were reading and filled the squares, I sat at the class talking to each student individually. I would look at the date, the book, and I would also ask them a little bit about the book because we did not have a test at that time for those books. Today, every book has a test that you could give through the internet such as the ones available in Mreader and XReading. This can be done by answering the questions we usually have in the graded readers or by setting tests in Mreader.

As a teacher, you can use the methods I mentioned before but more importantly you also have to think about what the record keeping is for. If the record keeping is to impress the other teachers or the principals of the school on whatever of the progress that is being made, then about every year you should give a vocabulary test to show that students' vocabulary size is increasing. You should report on the number of books the students are reading and the levels they have passed through. These are among others that you can report to show progress.

Some teachers may also do a pre-test and post-test to assess the students' vocabulary mastery progress. For this, I would like to point out that there are problems of having pre-test and post-test to check students' vocabulary 
mastery during extensive reading program. The problems occur if you do not have a lot of time between pre-test and post-test with learners doing a lot of reading. Therefore, people often make mistakes in doing an experiment on ER, that is, instead of basing the vocabulary test on the words that the learners need onto reading, they just use a standardized vocabulary test. As a result, the scores do not look so great because quite a few of the words on the test the learners never meet on the reading.

The reason for giving the test at the beginning is to make sure that you are getting the books at the right level. The test is not necessarily given to every learner; rather, it is just for some of them. If the learners only know a thousand words or less than a thousand words, then you have to get books for example at the 500, 700, 1000, 1500 and 2000 levels. Then, if everybody already knows almost all of the first 1000 of 1500 words, you will need books at the 1500 , 1700 , or 2000 levels. Provided with these right levels of books for the learners, you could after a year or two, give a vocabulary level test to look at the progress the students have made. In experimenting with ER you can analyze the books of students who read and test the vocabulary they have met because you could only learn from words that you meet. Therefore, you can then see how extensive reading as helping the students to learn the words that they meet.

\section{What would be your final comments related to extensive reading and its benefits?}

In doing extensive reading, I would be spending time getting the learners to read and to keep the ER program simple. It means to read at the right level and to do lots of reading. Other than the benefits of ER that we have discussed, extensive reading will also improve the students' motivation to read as it has been found effective based on quite a few research studies. Some research has also found out its effects on writing. It is only a small effect, however. It is because using productive skill to measure success in receptive skill is tough to test.

ER is not a method of language learning but it is a part of meaningfocused input and fluency development. Therefore, it is a highly important part of balanced learning in a language course especially in an English as a Foreign Language course. It brings the biggest improvement you can make in a language course compared to other changes because it makes the greatest 
proficiency gains. It is not a miracle, though. ER simply works because the more you meet the language, the more you will know about the language and be able to use it. It is as simple as that. It is simply the quantity of ER that increases the amount of input that learners get and if you increase the input, you increase the learning.

This has been a great opportunity to have an interview with Professor Paul Nation and we are thankful for the insight on extensive reading that he shared with us during the interview.

\section{REFERENCES}

Byun, J.-H. (2010). Korean EFL teachers' perspectives about their participation in an extensive reading program. (Doctoral dissertation, The University of Texas at Austin, Austin, Texas, USA).

Elley, W. B., \& Mangubhai, F. (1981). The impact of a book flood in Fiji primary schools. Wellington/Suva: New Zealand Council for Educational Research/Institute of Education at the University of the South Pacific.

Nation, I. S. P. (2007). The four strands. Innovation in Language Learning and Teaching, 1, 1-12. 